DOI https://doi.org/10.18551/rjoas.2021-02.01

\title{
A REVIEW ON FACTORS AFFECTING ADOPTION OF WHEAT IN ETHIOPIA: AN IMPLICATION FOR VARIETAL DEVELOPMENT
}

\author{
Siyum Negussie* \\ Sirinka Agricultural Research Center, Woldia, Ethiopia
}

Giziew Almaz

College of Agriculture and Environmental Sciences, Bahir Dar University, Ethiopia

*E-mail: negussiese@gmail.com

\begin{abstract}
The study is based on a narrative review approach using published sources in the area of agricultural technology adoption. Despite many improved varieties and agronomic practices have been released and recommended to the farmers, the adoption of these technologies remained below the expected figure. Hence it is pertinent to understand factors affecting wheat technology adoption in Ethiopia. Factors such as, Age of the farmer, farmers' learning and experience, family labor, field days, Sex, total active household labor in man equivalent, access to credit, livestock ownership, education of household head, trainings, demonstrations, extension contact, mass media, farm income, farm size and, access to all weather roads and market distance positively and significantly affect adoption of wheat by smallholder farmers. Therefore, measures such as, establishing better input supply, developing agricultural information system and availing farm machineries should be taken to overcome the above constraints of wheat technology adoption.
\end{abstract}

\section{KEY WORDS}

Adoption, technology, wheat, Ethiopia.

Agriculture is one of the central fields that shape the socioeconomic development of any country (Mohamad MRA and Gombe, 2017). Hence, the life of all human being is heavily dependent on agricultural products and its importance is going to increase day to day (Akhtar and Pirzada,2014). Consequently, Agriculture has for many years been the backbone of Africa economy and the potential sources of economic growth despite all its weaknesses (Ajao et al., 2013).

Agriculture is a dominant sector of Ethiopian economy which makes a lion share contribution to the Gross Domestic Product, employment and foreign exchange earnings. It is still believed to remain a sector that plays an important role in stimulating the overall economic development of the country in the years to come (CSA, 2014). Agriculture has continued to retain its importance in Ethiopia's economic growth contributing about $42 \%$ of GDP, with $80 \%$ of employment and $70 \%$ of export earnings in 2014 (African Economic Outlook, 2015) as cited by (Lulit Mitik et al., 2016).

More specifically, Cereal production occupies the major share of agricultural production in Ethiopia, of which teff, maize, wheat and sorghum are most important cereals in terms of area cultivate, yield and consumption. Teff constitutes almost $24 \%$ of total grain production, followed by maize (17\%), sorghum (15\%) and wheat (14\%) (CSA, 2014b) as cited in (Lulit et al. 2016). Most smallholder farmers are located in the moisture-reliable cereal based highlands accounting for $59 \%$ of all farm area; on the other hand, the farm area in the drought-prone highlands represents $27 \%$ of the total area cultivated (Lulit et al.,2016).

Ethiopia is the largest wheat producer in Sub-Saharan Africa with the cultivated land of 1.1 million ha (Mohammed et al., 2011). Of the cereal crops, wheat is one of the staple crop in Ethiopia whose share in cereal acreage has remained constant since the 1980s unlike that of maize which has increased substantially over time (Abate et al., 2015). wheat is also among the most important staple food crops grown in Ethiopia (Shiferaw et al.,2014). There 
are two varieties of wheat grown in Ethiopia: durum wheat, accounting for 60 percent of production, and bread wheat, accounting for the remaining 40 percent (Bergh et al., 2012) as cited in (Gashaw et al., 2014).

Both bread wheat and durum wheat are grown in Ethiopia and. Of which, about $87 \%$ is grown during the main growing season (meher). While durum wheat is indigenous and mainly grown in the Central and Northern highlands bread wheat is a recent introduction to Ethiopia. Durum wheat was the main wheat crop both in terms of area and production, but this has altered dramatically since the mid-1980s with the release and diffusion of semidwarf, high yielding and adaptable bread wheat varieties (Bekele et al., 2014).

In many developing countries, like Ethiopia, it has become obvious that generating new technology alone has not provided solution to enable poor farmers to increase agricultural productivity and achieve higher standards of living (CIMMIYT 1993) as cited by (Bezabih 2012). According to previous researches in Ethiopia, low adoption of improved production technologies was attributed to unavailability of appropriate technologies, unavailability and high cost of required inputs, lack of access to and high interest rates on credit, and policies that discourage improved technology adoption such as promotion of state farms (Hailu Abera 2008). Increasing the rates of adoption of improved production technologies is therefore considered critical for agricultural growth in Ethiopia. Therefore this study will add a value for literature on determinants of agricultural technology adoption specifically in wheat production packages.

Table 1 - Improved wheat varieties released in Ethiopia

\begin{tabular}{|c|c|c|c|}
\hline \multirow{2}{*}{ Year } & \multicolumn{3}{|c|}{ Released Improved Wheat varieties (Number) } \\
\cline { 2 - 4 } & Bread wheat & Durum wheat & Total \\
\hline Before 1981 & 3 & - & 4 \\
\hline $1981-1990$ & 3 & 1 & 23 \\
\hline $1991-2000$ & 15 & 8 & 45 \\
\hline $2001-2010$ & 25 & 20 & 85 \\
\hline Total & 46 & 39 & 4 \\
\hline
\end{tabular}

Source: Chilot et al., 2013.

The general objective of the study is to review factors affecting the adoption of wheat technologies and review farmers varietal perception towards improved wheat technologies.

Specific objectives:

- To identify factors affecting the adoption of wheat;

- To review farmers varietal perception towards improved wheat;

- To review existing models/theories of adoption.

\section{METHODS OF RESEARCH}

Narrative review approach was employed for meeting the above stated objectives. In this regard selected studies were compared and summarized on the basis of the author's experience, existing theories and models using tables and narrations. It was tried to present the latest researches in the given topic or field of research.

\section{LITERATURE REVIEW}

The focus of technology adoption studies is mainly on estimating adoption rates and its understanding the relationship between technology adoption, its intensity and relevant socioeconomic, and policy variables. Despite their importance in explaining some of the bottlenecks to technology adoption, the problem arises from biased estimates of both adoption rates as well as determinants of adoption when applied to a population that is not fully aware of the technology (Simtowe et al., 2011).

As cited in (Feder et al.,1985) the adoption process is defined by Rogers as "the mental process by an individual passing from first hearing about an innovation to its final 
adoption. However, for detailed theoretical and empirical analysis, a specific quantitative definition of adoption is needed. Such a definition must distinguish between individual (farm level) adoption and aggregate adoption. Final adoption at the individual farmer's level is defined as the degree of use of a new technology in long run equilibrium when the farmer has full information about the new technology and it's prospective. Through a process of learning and experimentation, new equilibrium levels can be achieved. From the aggregate adoption point of view, the diffusion process can be defined as "the process of transfer of a new technology within a region. Aggregate level of use of a specific new technology within a given geographical area or within a given population is measured in terms of Aggregate adoption is measured (Feder et al.,1985).

Usually, agricultural technologies are introduced in the form of packages that include several components, for instance, high-yielding improved varieties, fertilizer, and corresponding agronomic practices. Even though the components of a package may complement each other, some of them can be adopted separately. Thus, farmers may encounter various distinct technological choices. They may adopt either full package of innovations introduced in the region or subsets of the package that can be adopted disjointedly.

The individual and the choices an individual makes to accept or reject a particular innovation can examined by adoption theory. In some models, adoption is not only the choice to accept an innovation but also the level to which that innovation is incorporated into the appropriate context. Adoption theory, then, can be considered as a micro perspective on change, aiming not on the whole but rather the pieces that make up the whole. In contrary, diffusion theory represents how an innovation spreads through a population. It may consider factors such as, time and social pressures to describe the process of how a population adopts, adapts to, or rejects a particular innovation. Diffusion theory lies on a macro perspective on the spread of an innovation through time (Straub, 2009).

Adoption models embedded on a diversity of theories for example, Innovation Diffusion Theory (IDT) is from sociology, Theory of Reasoned Action (TRA) is from social psychology, and Theory of Interpersonal Behavior (TIB), Theory of Planned Behavior (TPB) and Social Cognitive Theory (SCT) are psychosocial theories. All three theories have proven their usefulness in predicting and explaining a variety of human behaviors in different contexts. Instead, TRA and TPB differ from DOI in the sense that the former emphases on explaining the behavior of individuals. While the latter concentrates on adoption decisions in which the organizational characteristics play a key role, not the individual. SCT and TPB integrate the notion of perceived outcomes when forecasting behavior while DOI and TAM focus solely on beliefs about the technology. DOI, TAM and TPB adopt a unidirectional outlook towards causal relationship, in which environmental constructs affect cognitive beliefs, which affect attitudes and behaviors whereas SCT relies on the bidirectional nature of causation in which behavior, emotional and cognitive factors and environment persistently and mutually affect each other (Taherdoost, 2018).

Everett Roger's grand work in 1960, named as the Diffusion of Innovation Theory is the foundation of research in diffusion. This theory has been widely applied by the researchers over the years. The main notion of the theory is that there are four basic elements that affect the spread of a new idea: the innovation, communication channels, time and social system. The process of diffusion comprises of five stages, i.e., knowledge, persuasion, decision, implementation, and confirmation Adopter categories are the classifications of members of a social system on the basis of innovativeness. Based on social system and innovativeness, adopters can be categorized into five; (1) innovators, (2) early adopters, (3) early majority, (4) late majority, and (5) laggards (E. M. Rogers,1983a).

Social psychology setting served as the basis in the theory of Reasoned Action (TRA). The theory proposes three general concepts, i.e. behavioral intention (BI), attitude (A), and subjective norm (SN). According to theory of reasoned action, a person's behavioral intention depends on his attitude and subjective norms. Arithmetically, it can be understood that behavioral intention is the summation of attitude and subjective norms. Furthermore, intention of a person is likely to change to action if there is the intention to behave in a 
specific manner is highly enough (Fishbein and Ajzen, 1975) as cited by (Assomption et al.,1993).

The Theory of Planned Behavior (TPB) was proposed by Icek Ajzen in 1991 and was emanated from the Theory of Reasoned Action. TPB includes the concept of Perceived Behavioral Control (PBC) to the basis attitudes and subjective norms which make up the TRA. Perceived behavioral control denotes to "people's perception of the ease or difficulty of executing the behavior of interest". It diverges from Rotter's (1966) concept of perceived locus of control because it is not constant and varies with different circumstances faced by the individual. The Locus of control is considered to be a more general expectancy of the individual which remains equally stable across situations. In this way, the critics faced by TRA that it is based on relatively static build of attitude and thus cannot be used for estimate of behavioral outcome has been addressed by TPB. The basis of concept of PBC are stranded in the Self Efficacy Theory (SET) proposed by Bandura (1977) which in turn came from the Social Cognitive Theory (Straub 2009).

The focus of the Social Cognitive Theory (SCT) is on the concept of self-efficacy which is defined as "the judgment of one's capability to use a technology to complete a specific job or task". According to SCT, behavior of the user is affected by anticipations of result related to personal as well as performance-related gains. Self-efficacy, in turn, effects the expectation of outcome of both types. Whereas, esteem of the person and his sense of success relate to personal outcome expectations, outcome expectations related to performance on the job lead to performance related expectations. According to SCT, there are two contrasting causes that influence behavior of the users. Encouraging impact is made by the factor "affect" which is the extent to which an individual likes his job. Instead, negative contribution to preferred behavior is made by the factor "anxiety" which is the anxious response of the person while performing a job such as trying to use a computer with which the person is not very familiar. This theory has been extensively employed in adoption studies (Bandura, 1986) as cited by (Straub, 2009).

Technology Adoption Model (TAM) has been intensively applied in technology adoption research. The strength of the model lies in its simplicity as it has only two basis, namely, "perceived usefulness" and "perceived ease of use" for predicting extent of adoption of new technologies at individual level as shown below (Venkatesh and Davis, 2000).

The Model of PC Utilization is built on the Theory of Human Behavior by Triandis (1977) which deviates in some ways from the Theory of Reasoned Action because it makes a discrepancy between cognitive and affective components of attitudes. Beliefs belong to the cognitive element of attitudes. According to this theory "Behavior is determined by what people would like to do (attitudes), what they think they should do (social norms), what they have frequently done (habits), and by the anticipated consequences of their behavior"(Triandis, 1977) as cited by (Sharma and Mishra, 2014).

The key concept behind Motivation Model is Motivation theory of psychology (Davis, Bagozzi and Warshaw 1992). Several studies have examined motivational theory and revised it for specific situations and also applied it to recognize new technology adaption and use. The core constructs of the theory are extrinsic motivation and intrinsic motivation (Davis, Bagozzi and Warshaw 1992) as cited by (Samaradiwakara and Gunawardena, 2014).

Venkatesh \& Davis modified TAM to include extra key factors of TAM's perceived usefulness and usage intention basis in their extended TAM model. The additional constructs incorporated social influence processes (subjective norm, voluntariness and image) and cognitive influential procedures (job relevance, output quality, result demonstrability and perceived ease of use) (Venkatesh and Davis, 2000).

Unified Theory of Acceptance and Use of Technology commonly referred as UTAUT was postulated in 2003 by Venkatesh et.al. By a systematic review and association of the constructs of previous eight models (TRA, TAM, MM, TPB, TAM2, DOI, SCT and model of personal computer use). It is meant to serve as an inclusive model that can be applied across a variety of applications. It comprised of four basic constructs namely "performance expectancy, effort expectancy, social influence and facilitating conditions. The unified theory is supposed to be superior as it is able to explain $70 \%$ of the variance while the former 
theories were explaining only $30-40 \%$ variance in the adoption behavior. However, it confronts criticism on the grounds of being too complex, not being thrifty in its approach and its inability to explain individual behavior (Chiemeke and Evwiekpaefe 2011).

Model of Acceptance with Peer Support (MAPS) offers an integration of earlier research that was focused on individuals with pertinent constructs of social network in such a way that helps to extend the scope of earlier theories. There are two types of social ties which the authors proposed. First tie exists between employees relates to obtaining assistance from employees that can result in extension of knowledge for using the system. The second kind of tie between employees is related to providing support to co-workers for enabling better understanding of configuration and deployment of the system (Sharma and Mishra 2014).

Table 2 - Summary of Theories and Models of Technology Adoption

\begin{tabular}{|c|c|c|c|}
\hline Year & Theory/Model & $\begin{array}{l}\text { Developed } \\
\text { by }\end{array}$ & Constructs/ Determinants of adoption \\
\hline 1960 & $\begin{array}{l}\text { Diffusion of innovation } \\
\text { Theory }\end{array}$ & $\begin{array}{l}\text { Everett } \\
\text { Roger }\end{array}$ & $\begin{array}{l}\text { The innovation, communication channels, time and social } \\
\text { system }\end{array}$ \\
\hline 1975 & $\begin{array}{l}\text { Theory of reasoned } \\
\text { action }\end{array}$ & $\begin{array}{l}\text { Ajzen and } \\
\text { Fishbein }\end{array}$ & Behavioral intention, Attitude (A), and Norm \\
\hline 1986 & $\begin{array}{l}\text { Social Cognitive } \\
\text { theory }\end{array}$ & Bandura & Affect, anxiety \\
\hline 1989 & Technical Adoption & Fred D Davis & Perceived usefulness and perceived ease of use \\
\hline 1991 & $\begin{array}{l}\text { The Model of PC } \\
\text { Utilization }\end{array}$ & $\begin{array}{l}\text { Thompson et } \\
\text { al. }\end{array}$ & $\begin{array}{l}\text { Job-fit, Complexity, Long-term consequences, Affect Towards } \\
\text { Use, Social Factors }\end{array}$ \\
\hline 1992 & The Motivation model & Davis et al. & $\begin{array}{l}\text { Extrinsic motivation (such as perceived usefulness, perceived } \\
\text { ease of use, and subjective norm) and intrinsic motivation }\end{array}$ \\
\hline 2000 & Extended TAM2 model & $\begin{array}{l}\text { Venkatesh } \\
\text { and Davis }\end{array}$ & $\begin{array}{l}\text { Social influence processes (subjective norm, voluntariness and } \\
\text { image) and cognitive instrumental processes (job relevance, } \\
\text { output quality, result demonstrability and perceived ease of use) }\end{array}$ \\
\hline 2003 & Unified Theory of & $\begin{array}{l}\text { Venkatesh et } \\
\text { al. }\end{array}$ & $\begin{array}{l}\text { Performance expectancy, effort expectancy, social influence } \\
\text { and facilitating conditions }\end{array}$ \\
\hline 2009 & $\begin{array}{l}\text { Model of acceptance } \\
\text { with Peer Support } \\
\text { (MAPS) }\end{array}$ & Sykes et al. & $\begin{array}{l}\text { Behavioral intention, System use, Facilitating conditions, } \\
\text { Network density, Network centrality, Valued network centrality, } \\
\text { Valued network density }\end{array}$ \\
\hline
\end{tabular}

\section{RESULTS AND DISCUSSION}

There are various studies conducted in the area of adoption specifically in agricultural technologies. According to (D'Souza and Mishra, 2018) a study on 'Adoption and Abandonment of Partial Conservation Technologies in Developing Economies: The Case of South Asia', years of education, credit access and membership to different clubs significantly affect the adoption of partial conservation. For instance compared with heads of the households with primary education, household heads with secondary education and tertiary education household heads are more likely to adopt partial conservation technologies.

Another study (Akinola et al., 2010), Determinants of adoption and intensity of use of balance nutrient management systems technologies in the northern Guinea savanna of Nigeria; identified asset owner ship and off farm income as significant factors in determining adoption of balanced nutrient management. Similar with (D'Souza and Mishra, 2018), Akinola et al, 2010) indicated access to credit as determinant factor of adoption.

According to (Solomon, Tessema, and Bekele 2014) a study conducted in Oromia region, Ethiopia, credit access, household head sex, field day participation, access to all weather roads, access to credit, active family force, district and market distance as being key determinants on the intensity and adoption of use of improved wheat varieties. Hence, the study recommended that emphasize should be given to this variables to improve adoption and intensity of wheat.

(Hailu Abera 2008) identified farm size, family labor and farmers' education as critical factors in determining adoption of tef and wheat technologies. Farm size has a positive influence on the adoption of tef and wheat technologies. The findings of this author indicated 
that policies and strategies should be put in place in expanding primary education to improve the understanding of farmers towards herbicide application. In this study teff and wheat are identified as labor intensive technologies indicating that labor plays a paramount importance in adopting these technologies. Similarly (Manda et al, 2016) argues that, education level of the household head has a positive and significant influence on adoption of improved maize varieties. In addition to this, Manda and his colleagues result shows that access to extension services increases the likelihood of adoption of maize varieties.

According to (Ermias, 2013) a study conducted in North Wollo, the level of active labor ratio negatively and significantly affects adoption and intensity of improved sorghum varieties. Another determinant factor according to this study is the extent of livestock ownership which significantly and positively affects adoption and intensity of use of improved sorghum varieties. Contrary to (Hailu, 2008), (Ermias, 2013) found out that Farm size as determinant factor which negatively and significantly affects adoption and intensity of use of improved sorghum varieties.

The results of adoption studies by (Khonje et al. 2015), (Bezu et al. 2014), and (Rahman and Haque 2013), reveal that education level of the household head has appositive and significant effect on adoption of a given agricultural technologies. (Bezabih, 2012) found out that frequency of contact with extension agents, exposure of mass media and participation on extension events has a positive significant effect on adoption of wheat technologies.

Findings from (Arslan et al., 2014) a research conducted on Adoption and intensity of adoption of conservation farming practices in Zambia, indicated that age of the household head and education level significantly increase the intensity of adoption of conservation farming practices, while cultivated land per capita decreases the intensity of adoption, resulted from labor constraints.

According to (Solomon et al., 2014) factors such as, household head sex, credit access, active family force, access to all-weather roads, district and market distance had a significant effect on the intensity of use of wheat varieties at different significance levels.

Access to credit positively and significantly influences the adoption and use intensity of balanced nutrient management systems (BNMS). An additional source of credit results an increase of the probability of adoption of BNMS-manure by $11 \%$. Hence, an improvement in access to formal or informal credit will enhance households' technology adoption according to the findings of this study.

A study conducted by (Ermias etal, 2014) indicated that field day participation, access to all weather roads, access to credit, active family force, district and market distance significantly affect the adoption wheat varieties. According to (Laduber etal., 2016), Institutional factors overweighed than individual, economic and kebele level factors for the adoption of bread wheat.

On the other hand, a study conducted in southern Ethiopia by (Worku and Yishak, 2017) showed that education status, household size in adult equivalent, oxen ownership, and participation in agricultural training and demonstrations significantly affect the adoption of planting method of wheat.

Apart from household characteristics and farmers' knowledge (Hassen, 2014) in his study on the adoption of wheat seed, concluded that distance to different infrastructures such as (markets, roads, and input supply) play a significant role for technology adoption. This result is in agreement with the findings of (Degefu et al, 2017) conducted in Eastern Ethiopia, Hararghe.

The study by (Bedilu et al. 2015) revealed that, farming experience, distance to cooperatives, renting a tractor and combine harvester, Urea application, and net income from wheat grain sale positively and significantly affect wheat technology adoption.

Knowledge and information on farmers' perception and its influence on adoption of modern wheat varieties, awareness and source of new wheat production technology practices remain erratic in Ethiopia. There is an extensive adoption of new technologies: the majority of farmers grew modern wheat varieties (Zewdie et al, 2010). 
Since farmers view agricultural technologies as a complex of embodiment of several attributes, no single technology-specific attribute can cover the dimension of farmer's perception of technology- specific attributes. Technology-specific attributes that were used in the current study were relative advantage, compatibility, trialability, complexity and observability (Njane and Wangare, 2007).

Table 3 - Summary of literatures on adoption of wheat technologies in Ethiopia

\begin{tabular}{|c|c|c|c|c|c|}
\hline No & $\begin{array}{l}\text { Author(s), } \\
\text { year }\end{array}$ & Model used & $\begin{array}{l}\text { Kind of } \\
\text { technology }\end{array}$ & Study Areas & Important findings \\
\hline 1. & $\begin{array}{l}\text { Hailu } \\
\text { Abera } \\
(2008)\end{array}$ & $\begin{array}{l}\text { Xtprobit and } \\
\text { Xttobit } \\
\text { random effect }\end{array}$ & $\begin{array}{l}\text { Tef and wheat } \\
\text { technologies }\end{array}$ & $\begin{array}{l}\text { Northern and } \\
\text { Western Shewa, } \\
\text { Amhara Region }\end{array}$ & $\begin{array}{l}\text { Age of farmer, farmers' learning } \\
\text { and experience, family labor and } \\
\text { credit }\end{array}$ \\
\hline 2. & $\begin{array}{l}\text { Tariku } \\
\text { Bezabih, } \\
2012\end{array}$ & Tobit model & $\begin{array}{l}\text { Wheat and } \\
\text { production } \\
\text { technologies }\end{array}$ & $\begin{array}{l}\text { Gesha District, } \\
\text { Kaffa zone, SNNP }\end{array}$ & $\begin{array}{l}\text { Sex, education of household, } \\
\text { trainings, field days, } \\
\text { demonstrations, extension, mass } \\
\text { media, farm income, farm size and } \\
\text { livestock ownership }\end{array}$ \\
\hline 3. & $\begin{array}{l}\text { Tesfaye } \\
\text { etal, (2014) }\end{array}$ & $\begin{array}{l}\text { Double } \\
\text { Hurdle }\end{array}$ & Wheat varieties & $\begin{array}{l}\text { Robe and Digelu } \\
\text { Tijo Districts of Arsi } \\
\text { Zone in Oromia } \\
\text { Region }\end{array}$ & $\begin{array}{l}\text { Hh sex, field day participation, } \\
\text { access to all weather roads, } \\
\text { access to credit, active family } \\
\text { force, district and market distance }\end{array}$ \\
\hline 4. & $\begin{array}{l}\text { Zegeye, T. } \\
\text { et al. } \\
(2001)\end{array}$ & logistic model & $\begin{array}{l}\text { Wheat varieties } \\
\text { and inorganic } \\
\text { fertilizer }\end{array}$ & $\begin{array}{l}\text { Yelmana Densa } \\
\text { and Farta district } \\
\text { Amhara Region }\end{array}$ & $\begin{array}{l}\text { Farm size, on-farm demonstration, } \\
\text { Contacts with extension agent, } \\
\text { cooperative representatives }\end{array}$ \\
\hline 5. & $\begin{array}{l}\text { Laduber et } \\
\text { al., } 2016\end{array}$ & $\begin{array}{l}\text { Logistic } \\
\text { regression }\end{array}$ & Bread wheat & $\begin{array}{l}\text { Yilmana Densa } \\
\text { District, West } \\
\text { Gojam, Amhara } \\
\text { region }\end{array}$ & $\begin{array}{l}\text { Institutional factors overweighed } \\
\text { than individual, economic and } \\
\text { kebele level factors }\end{array}$ \\
\hline 6. & $\begin{array}{l}\text { Worku and } \\
\text { Yishak, } \\
2017\end{array}$ & $\begin{array}{l}\text { Binary logistic } \\
\text { regression }\end{array}$ & $\begin{array}{l}\text { Planting } \\
\text { method }\end{array}$ & $\begin{array}{l}\text { Sodo Zuria } \\
\text { Woreda, Southern } \\
\text { Ethiopia }\end{array}$ & $\begin{array}{l}\text { Sex of the household, education } \\
\text { status, household size in adult } \\
\text { equivalent, oxen ownership, and } \\
\text { participation in agricultural training } \\
\text { and demonstrations }\end{array}$ \\
\hline 7 & $\begin{array}{l}\text { Hassen } \\
\text { Beshir, } \\
2012\end{array}$ & Double hurdle & Wheat seed & $\begin{array}{l}\text { Dessie Zuria and } \\
\text { kutaber districts of } \\
\text { Wollo }\end{array}$ & $\begin{array}{l}\text { Distance to markets, roads, and } \\
\text { input supply play a significant role } \\
\text { for technology adoption }\end{array}$ \\
\hline 8 & $\begin{array}{l}\text { Belay, } \\
2017\end{array}$ & Logit & $\begin{array}{l}\text { Improved wheat } \\
\text { technology }\end{array}$ & $\begin{array}{l}\text { Gozzamen District, } \\
\text { East Gojjam } \\
\text { Amhara region }\end{array}$ & $\begin{array}{l}\text { Education, farm size, total active } \\
\text { household labor in man equivalent, } \\
\text { crop income, input, contact } \\
\text { extension agent, off farm income } \\
(+)\end{array}$ \\
\hline 9 & $\begin{array}{l}\text { Degefu, } \\
2017\end{array}$ & $\begin{array}{l}\text { Two-limit } \\
\text { Tobit model }\end{array}$ & $\begin{array}{l}\text { Wheat } \\
\text { Production } \\
\text { Technology } \\
\text { Package }\end{array}$ & $\begin{array}{l}\text { Eastern Ethiopia } \\
\text { Hararghe }\end{array}$ & $\begin{array}{l}\text { District, gender, age of the } \\
\text { household, education status of the } \\
\text { household, farm size, distance to } \\
\text { market, and FTC, Cooperative } \\
\text { membership, dependency ratio, } \\
\text { and annual income }\end{array}$ \\
\hline 10 & $\begin{array}{l}\text { Bedilu, et } \\
\text { al., } 2015\end{array}$ & $\begin{array}{l}\text { Tobit model } \\
\text { and Double- } \\
\text { hurdle model }\end{array}$ & $\begin{array}{l}\text { improved bread } \\
\text { wheat varieties }\end{array}$ & $\begin{array}{l}\text { Southeastern } \\
\text { Highland of } \\
\text { Ethiopia }\end{array}$ & $\begin{array}{l}\text { farming experience, distance to } \\
\text { cooperatives, renting a tractor and } \\
\text { combine harvester, Urea } \\
\text { application, and net income from } \\
\text { wheat grain sale }\end{array}$ \\
\hline 11 & $\begin{array}{l}\text { Chilot, et al } \\
2013\end{array}$ & Tobit & $\begin{array}{l}\text { Improved wheat } \\
\text { technologies }\end{array}$ & In Ethiopia & $\begin{array}{l}\text { Education of the household head, } \\
\text { ownership of oxen and corrugated } \\
\text { roofed house(as proxy for wealth) } \\
(+)\end{array}$ \\
\hline
\end{tabular}

Complexity is the degree to which an innovation is perceived as relatively difficult to understand and use. Any new idea may be classified on the complexity-simplicity continuum. Some innovations are clear in their meaning to potential adopters while others are not.

The complexity of an innovation, as perceived by members of a social system, is negatively related to its rate of adoption. 
Trialability is the degree to which an innovation may be experimented with on a limited basis. New ideas that can be tried on the installment plan will generally be adopted more rapidly than innovations that are not divisible. An innovation that is trial able is less uncertain for the adopter. Some innovations are more difficult to divide for trial than others. Laggards move from initial trial to full-scale use more rapidly than do innovators and early adopters. The more innovative individuals have no precedent to follow when they adopt, while the later adopters are surrounded by peers who have already adopted the innovation. These peers may act as a psychological or vicarious trial for the later adopters, and hence, the actual trial of a new idea is of less significance for them.

Observability is the degree to which the results of an innovation are visible to others. The results of some ideas are easily observed and communicated to others, whereas some innovations are difficult to describe to others. A technology has two components: (1) a hardware aspect that consists of the tool that embodies, the technology as material or physical objects, and (2) a software aspect that consists of the information base for the tool. Usually the software component of a technological innovation is not so apparent to observation, so innovations in which the software aspect is dominant possess less observability, and usually have relatively slower rates of adoption.

Relative advantage is the degree to which an innovation is perceived as being better than the idea it supersedes. The degree of relative advantage is often expressed in economic profitability, in status giving, or in other ways. The nature of the innovation largely determines what specific type of relative advantage (such as economic, social, and the like) is important to adopters, although the characteristics of the potential adopters also affect which dimensions of relative advantage are most important.

The choice of these attributes was based on the fact that, they can be used to describe any agricultural technology as opposed to those technology-specific attributes that are very specific. For instance, taste, cooking quality, among others, which are only applicable to technologies whose end output, is directly consumable. Farmer's perception of technologyspecific attributes were measured by asking a farmer to express his/her opinion as either strongly agree, agree, uncertain, disagree and strongly disagree on perception statements presented to the farmer (Njane and Wangare, 2007).

A study by Zewdie and Dawit (2017), followed two steps in order to elicit farmers' preferences for bread wheat. First, they identified the list of attributes that helps farmers to characterize the different varieties of bread wheat through consulting wheat breeders and agronomists and then validating with farmers. Thus, grain yield, seed size, seed color, early maturity, drought tolerance, resistance to rusts (Puccinia striiformis $\mathrm{f}$. $\mathrm{sp}$. tritici and $\mathrm{P}$. graminis f. sp. tritici), threshability, field establishment (germination, seedling emergence and growth) and crop stand, bread making quality, marketability, straw yield and straw quality were identified accordingly. Second, they elicited farmers' perceptions using these traits for the local and improved bread wheat varieties currently under cultivation (Zewdie and Dawit, 2017).

\section{CONCLUSION}

This paper reviewed the determinants to adopt improved wheat production packages. Although wheat is among the most important staple food crops grown in Ethiopia, the rate of adoption and dissemination of the technology is found to be very minimal. As result, the country still remained a net importer of wheat despite its potentials. The adoption of wheat technology has very significant effect on yield improvement.

Even though many micro studies have been conducted on adoption of wheat in Ethiopia, most of them are based on cross sectional data. But adoption by its nature is a dynamic process which can't be fully addressed by using a cross sectional data. Literatures in the area of agricultural technology adoption have come up with different results in identifying determinants of wheat technology adoption by smallholder farmers. These factors fall into four categories; demographic, economic, institutional and psychological. Hence after reviewing relevant literatures above, the following policy implications can be drawn: 
- Provision of adequate and relevant agricultural extension services (such as training on improved bread wheat agronomic practices and demonstration) should be given to enhance farmer's awareness about the technologies;

- Input supply systems (seed, chemical fertilizer and farm machineries) should be improved to increase the adoption of wheat technology packages;

- Access to infrastructures (such as roads and markets) should be given great attention;

- Agricultural information system should be established well to increase farmers' exposure for improved agricultural practices and market information(institutional factors);

- Wheat variety development strategies should be incorporate farmers' preferences.

\section{REFERENCES}

1. Ajao, A. O; Ogunniyi, L.T and Oyedele, G. A. 2013. "Agricultural Productivity Growth and Incidence of Poverty: An Experience from Africa." Journal of Economics and Sustainable Development 4 (5): 207-15.

2. Akhtar, Kalsoom. 2014. "SWOT Analysis of Agriculture Sector of Pakistan." Journal of Economics and Sustainable Development 5 (11): 127-34.

3. Akinola, A. A., Arega D. Alene, R. Adeyemo, D. Sanogo, A. S. Olanrewaju, C. Nwoke, and G. Nziguheba. 2010. "Determinants of Adoption and Intensity of Use of Balance Nutrient Management Systems Technologies in the Northern Guinea Savanna of Nigeria." Quarterly Journal of International Agriculture 49 (1): 25-45.

4. Arslan, Aslihan, Nancy McCarthy, Leslie Lipper, Solomon Asfaw, and Andrea Cattaneo. 2014. "Adoption and Intensity of Adoption of Conservation Farming Practices in Zambia." Agriculture, Ecosystems and Environment. https://doi.org/10.1016/j.agee.2013.08.017.

5. Assomption Mahougbe Hounsa, Gaston Godin, Eusebe Alihonou, Pierre Valois, Jacques Girard. 1993. "An application of Ajzen' s theory of planned behaviour to predict mothers ' intention to use oral rehydration therapy in a rural" 37 (2): 253-61.

6. Bedilu Demissie, Kedir Adem, Hussien H. Komicha, and Sisay Asefa. 2015. "Determinants of Adopting Improved Bread Wheat Varieties in Southeastern Highland of Ethiopia : A Double-Hurdle Approach." In Fall Conference: The Golden Age of EvidenceBased Policy.

7. Bekele Shiferaw, Menale Kassie, Moti Jaleta, and Chilot Yirga. 2014. "Adoption of Improved Wheat Varieties and Impacts on Household Food Security in Ethiopia." Food Policy 44 (February): 272-84.

8. Hassen Beshir,. 2014. "Factors Affecting the Adoption and Intensity of Use of Improved Forages in North East Highlands of Ethiopia." American Journal of Experimental Agriculture 4 (1): 12-27. https://doi.org/10.9734/AJEA/2014/5481.

9. Tariku Bezabih,. 2012. "Study on the Intensity and Adoption of Improved Wheat Varieties and Associated Agronomic Practices in Kaffa Zone, The Case of Gesha Woreda." Indira Gandhi National Open University (IGNOU). http://repository.smuc.edu.et/

10. Sosina Bezu,, Girma T Kassie, Bekele Shiferaw, and Jacob Ricker-Gilbert. 2014. "Impact of Improved Maize Adoption on Welfare of Farm Households in Malawi: A Panel Data Analysis." World Development 59 (July): 120-31.

11. Zewudie Bishaw, and Dawit Alemu. 2017. "Farmers' Perceptions on Improved Bread Wheat Varieties and Formal Seed Supply in Ethiopia." International Journal of Plant Production.

12. Bishaw Zewdie, P. C. Struik, and A. J.G. van Gastel. 2010. "Wheat Seed System in Ethiopia: Farmers' Varietal Perception, Seed Sources, and Seed Management." Journal of New Seeds. https://doi.org/10.1080/1522886X.2010.518302.

13. Brauw, Alan De, Tanguy Bernard, Gashaw Tadesse Abate, and Nicholas Minot. 2014. "The Impact of the Use of New Technologies on Farmers Wheat Yield in Ethiopia: Evidence from a Randomized Controlled Trial." International Food Policy Research Institute. Addis Ababa. 
14. Chiemeke, S C, and A E Evwiekpaefe. 2011. "A Conceptual Framework of a Modified Unified Theory of Acceptance and Use of Technology (UTAUT ) Model with Nigerian Factors in E-Commerce Adoption." Educational Research 2 (December): 1719-26.

15. Chilot Yirga, Moti Jaleta, Ali Mohammad, Bekele Shiferaw, Groote Hugo de, Menale Kassie, and Takele Mebratu. 2013. "Analysisof Adoption and Diffusion of Improved Wheat Technologies inEthiopia Analysis of Wheat Technologies." Addis Ababa.

16. CSA. 2014. "The Federal Democratic Republic of Ethiopia Central Statistical Agency Agricultural Sample Survey Report on Area, Production and Farm Mangement." Vol. V. Addis Ababa.

17. D'Souza, Alwin, and Ashok K. Mishra. 2018. "Adoption and Abandonment of Partial Conservation Technologies in Developing Economies: The Case of South Asia." Land Use Policy 70 (October 2017): 212-23. https://doi.org/10.1016/j.landusepol.2017.10.015.

18. Degefu Kebede, Mengistu Ketema, Nigussie Dechassa, and Feyisa Hundessa. 2017. "Turkish Journal of Agriculture - Food Science and Technology Determinants of Adoption of Wheat Production Technology Package by Smallholder Farmers: Evidences from Eastern Ethiopia" 5 (3): 267-74.

19. Ermias Tesfaye. 2013. "Adoption of Improved Sourghom Variety Triat Preference in Kobo distict,North Wolo zone,Ethiopia." Haramaya University.

20. Feder, Gershon, David Zilberman, and Richard E. Just. 1982. "Adoption of Agricultural Innovation in Developing Countries SWP542." 542. Washington, D.C.

21. Hailu Beyene. 2008. "Adoption of Improved Tef and Wheat Production Technologies in Crop- Livestock Mixed Systems in Northern and Western Shewa Zones of Hailu Beyene Abera." https://repository.up.ac.za/

22. Khonje, Makaiko, Julius Manda, Arega D. Alene, and Menale Kassie. 2015. "Analysis of Adoption and Impacts of Improved Maize Varieties in Eastern Zambia." World Development 66 (February): 695-706.

23. Laduber Wondale, Dessalegn Molla, and Daniel Tilahun. 2016. "Logit Analysis of Factors Affecting Adoption of Improved Bread Wheat (Triticum Aestivum L.) Variety: The Case of Yilmana Densa District, West Gojam, Ethiopia." Journal of Agricultural Extension and Rural Development 8 (12): 258-68. https://doi.org/10.5897/JAERD2016.0768.

24. Lulit Mitik, Bekele Shiferaw, Amarendra Sahoo, and Sika Gbegbelegbe. 2016. "EconomyWide Impacts of Technological Change in Food Staples in Ethiopia: A Macro-Micro Approach." Nairobi.

25. Manda, Julius, Arega D. Alene, Cornelis Gardebroek, Menale Kassie, and Gelson Tembo. 2016. "Adoption and Impacts of Sustainable Agricultural Practices on Maize Yields and Incomes: Evidence from Rural Zambia." Journal of Agricultural Economics. https://doi.org/10.1111/1477-9552.12127.

26. Worku Mentire, and Yishak Gecho. 2017. "Factors Affecting Adoption of Wheat Row Planting Technology: The Case of Sodo Zuriya Woreda, Wolaita Zone, Southern Ethiopia. December, 2016." Online).

27. Mohamad. 2017. "eAgriculture Revisited: A Systematic Literature Review of Theories, Concept, Practices, Methods, and Future Trends Title eAgriculture Revisited: A Systematic Literature Review of Theories, Concept, Practices, Methods, and Future Trends E-Agriculture R." http://usir.salford.ac.uk/43648/.

28. Njane, BY, and Philis Wangare. 2007. "Determinants of Adoption of Improved Wheat Varieties and Fertilizer Use by Small Holder Farmers in Njoro and Kieni West Divisions." Egerton University.

29. Rahman, M S, and Zerina Haque. 2013. "Adoption of Selected Wheat Production Technologies in Two Northern Districts of Bangladesh" 3 (1): 5-11.

30. Rogers, Everett M, and M Everett. n.d. DIFFUSION OF Third Edition.

31. Samaradiwakara, G D M N, and C G Gunawardena. 2014. "Sciences Journal European Scientific Institute (ESI )." International Technical Sciences Journal 1 (1).

32. Sharma, Rajesh, and Rajhans Mishra. 2014. "A Review of Evolution of Theories and Models of Technology Adoption." Indore Manage.J 6 (2): 17-29. 
33. Bekele Shiferaw,, Menale Kassie, Moti Jaleta, and Chilot Yirga. 2014. "Adoption of Improved Wheat Varieties and Impacts on Household Food Security in Ethiopia." Food Policy 44 (February): 272-84.

34. Simtowe, Franklin, Solomon Asfaw, Tsedeke Abate, 2011. "Determinants of Agricultural Technology Adoption under Partial Population Awareness: The Case of Pigeonpea in Malawi." https://doi.org/10.1186/s40100-016-0051-z.

35. Tesfaye Solomon, Ayele Tessema, and Adam Bekele. 2014. "African Journal of Agricultural Research Adoption of Improved Wheat Varieties in Robe and DigeluTijo Districts of Arsi Zone in Oromia Region, Ethiopia: A Double-Hurdle Approach." African Journal of Agricultural Research 9 (51): 3692-3703.

36. Straub, Evan T. 2009. "Understanding Technology Adoption: Theory and Future Directions for Informal Learning." Review of Educational Research 79 (2): 625-49. https://doi.org/10.3102/0034654308325896.

37. Taherdoost, Hamed. 2018. "A Review of Technology Acceptance and Adoption Models and Theories." In Procedia Manufacturing, 22:960-67. Tirgu-Mures, Romania: Elsevier B.V. https://doi.org/10.1016/j.promfg.2018.03.137.

38. Venkatesh, Viswanath, and Fred D Davis. 2000. "Theoretical Acceptance Extension Model : Field Four Studies of the Technology Longitudinal." INFORMS 46 (2): 186-204. 